University of Nebraska - Lincoln

DigitalCommons@University of Nebraska - Lincoln

Cell-Wall Composition and Accessibility to Hydrolytic Enzymes is Differentially Altered in Divergently Bred Switchgrass (Panicum virgatum L.) Genotypes

\author{
Gautam Sarath \\ Danny E. Akin \\ USDA-ARS \\ Robert B. Mitchell \\ USDA-ARS, rob.mitchell@ars.usda.gov \\ Kenneth P. Vogel \\ University of Nebraska-Lincoln, kvogel1@unl.edu
}

United States Department of Agriculture -Agricultural Research Service, Gautam.sarath@ars.usda.gov

Follow this and additional works at: https://digitalcommons.unl.edu/usdaarsfacpub

Sarath, Gautam; Akin, Danny E.; Mitchell, Robert B.; and Vogel, Kenneth P., "Cell-Wall Composition and Accessibility to Hydrolytic Enzymes is Differentially Altered in Divergently Bred Switchgrass (Panicum virgatum L.) Genotypes" (2008). Publications from USDA-ARS / UNL Faculty. 1962.

https://digitalcommons.unl.edu/usdaarsfacpub/1962

This Article is brought to you for free and open access by the U.S. Department of Agriculture: Agricultural Research Service, Lincoln, Nebraska at DigitalCommons@University of Nebraska - Lincoln. It has been accepted for inclusion in Publications from USDA-ARS / UNL Faculty by an authorized administrator of DigitalCommons@University of Nebraska - Lincoln. 


\title{
Cell-Wall Composition and Accessibility to Hydrolytic Enzymes is Differentially Altered in Divergently Bred Switchgrass (Panicum virgatum L.) Genotypes
}

\author{
Gautam Sarath • Danny E. Akin • Robert B. Mitchell • \\ Kenneth P. Vogel
}

Received: 12 December 2007 / Accepted: 29 January 2008/

Published online: 22 April 2008

(C) Humana Press 2008

\begin{abstract}
The aims of this study were to understand the genotypic variability in cell-wall composition and cell-wall accessibility to enzymes in select switchgrass plants obtained from two different populations derived from a base population of octaploid cultivars. Population $\mathrm{C}+3$ was developed by three breeding generations for high digestibility and population $\mathrm{C}-1$ developed by one generation of breeding for low digestibility. Aboveground biomass from 12 selected genotypes, three each with high or low digestibility within each population, was analyzed for their cell-wall aromatics and polysaccharides. The ratio of $p$-coumaric acid/ferulic acid was greater $(P \leq 0.05)$ for the high-lignin $\mathrm{C}-1$ population over the low-lignin $\mathrm{C}+3$ population, although the amounts of these two phenolics did not differ between populations. Combined values of guaiacyl+syringyl-lignin were consistently higher in genotypes from the $\mathrm{C}-1$ population as compared to the genotypes from the $\mathrm{C}+3$ population. Overall, $p$-coumaric acid was released by enzymes in greater amounts than ferulic acid in all these genotypes. Genotypes in the $\mathrm{C}-1$ population exhibited lower dry weight loss as compared to the genotypes in the $\mathrm{C}+3$ population after enzymatic digestion, suggesting changes in cell-wall architecture. Overall, our data highlight the phenotypic plasticity coded by the switchgrass genome and suggest that combining dry matter digestibility with other more specific cell-wall traits could result in genotypes with greater utility as bioenergy feedstocks.
\end{abstract}

Keywords Cell wall $\cdot$ Chemical analyses $\cdot$ Digestibility $\cdot$ Genotypes $\cdot$ Phenolic acids · Lignin $\cdot$ Sugars $\cdot$ Switchgrass $\cdot$ Enzymes

G. Sarath $(\bowtie) \cdot$ R. B. Mitchell $\cdot$ K. P. Vogel

Grain, Forage, and Bioenergy Research Unit, USDA-ARS, Department of Agronomy and Horticulture, East Campus, USDA-ARS, 314 Biochemistry Hall, Lincoln, NE 68583-0737, USA

e-mail: gautam.sarath@ars.usda.gov

D. E. Akin

Quality Assessment Research Unit, USDA-ARS, SAA, RBRRC, 950 College Station Road, Athens, GA 30605, USA 


\section{Introduction}

Switchgrass (Panicum virgatum $\mathrm{L}$.) is a perennial $\mathrm{C}_{4}$-prairie grass native to the tall-grass prairies of North America. Its natural range covers most of the continental USA except for regions west of the Rockies and north of $55^{\circ} \mathrm{N}$ latitude [1]. Switchgrass has been used as a forage crop for decades and is currently being developed as a bioenergy crop [1-5]. Use of switchgrass for bioenergy will require new cultivars to be bred with traits optimized for conversion in a biorefinery. Platforms currently under consideration include simultaneous saccharification fermentation [6], production of syngas (for example, [7]) or burning as a co-additive in boilers [8, 9]. Feedstock requirements for these platforms could vary significantly and require the development of switchgrass cultivars with unique traits that can meet specific conversion needs. Several of these traits will impact plant cell-wall composition, as the bulk $(\sim 70 \%)$ of harvested dry matter will arise from cell-wall components, namely, cellulose, hemicellulose and lignin [6]. The remaining components in the harvested biomass are cell soluble and minerals. Free phenolics present in the soluble fractions of herbaceous biomass could potentially be of economic importance [10], especially considering the projected scale of biorefineries [11]. Thus, understanding the extent to which switchgrass can be genetically manipulated into a valuable feedstock is of much interest to the nascent bioenergy sector.

Switchgrass has two main ecotypes: lowland and upland. Lowland ecotypes are all tetraploids, but upland ecotypes can be tetraploid or octaploid [12]. The octaploid plants are thought to have arisen through genome duplication of the tetraploid genomes [13]. Switchgrass is an obligate out-crosser with less than $1 \%$ seed arising from self-pollination. In nature, intermating between plants with different ploidy levels does not occur, but plants of the same ploidy will freely intermate resulting in considerable genotypic and phenotypic diversity within populations [14].

There is fairly extensive genetic variation within switchgrass populations, and these traits can be exploited through appropriate breeding methods. For example, switchgrass can be differentially bred for tillering [15], seed size [16, 17], yield [18], and dry matter digestibility (DMD) by ruminant animals. Selection of switchgrass and other forages for higher DMD generally results in lowering the lignin content of the plant $[19,20]$, which is a useful trait for forages, as it can improve weight gains by cattle on pastures [21, 22]. A single generation of divergent breeding for DMD in switchgrass induced changes in lignin concentration and also produced changes in some cell-wall alkali-labile phenolics [23]. However, lowering lignin content in both perennial and annual crop species can negatively impact fitness $[24,25]$ if fitness traits are ignored. These results demonstrate that it is possible to genetically alter the cell-wall composition of switchgrass and other herbaceous biomass plants. A detailed chemical evaluation of switchgrass plants that differ significantly in lignin concentration of their biomass is needed to quantify the range of changes that have occurred in cell-wall constituents including sugars, lignins, and phenolics.

In this paper, we have specifically evaluated the variability in cell-wall composition and cell-wall accessibility to enzymes in experimental switchgrass strains developed from a common base population by divergent breeding for biomass DMD [24, 26]. A population $(\mathrm{C}+3)$ that produced biomass with high $\mathrm{DMD}$ and low lignin was developed by three generations of selection for high DMD. A population $(\mathrm{C}-1)$ that produced biomass with low DMD and greater lignin concentration was produced by a single generation of selection for low forage DMD from the same base population [24, 26]. Because switchgrass cultivars and experimental strains consist of related populations of heterogeneous plants, they contain significant within-population genetic diversity [27, 28]. Plants in space-transplanted 
field nurseries of the $\mathrm{C}+3$ and the $\mathrm{C}-1$ switchgrass populations were sampled and analyzed for 2 years for stem, leaf, and sheath lignin. Twelve genotypes that differed widely for stem lignin concentration were extensively analyzed for cell-wall components.

Our results show that there was considerable variation in cell-wall components in these 12 genotypes. Although stem lignin was negatively correlated with DMD across populations, changes that occurred in phenolic and carbohydrate components were variable in different genotypes within populations.

\section{Materials and Methods}

\section{Plant Materials}

Switchgrass plants were selected from populations advanced for three cycles of high DMD $(\mathrm{C}+3)$ and for one cycle of low DMD $(\mathrm{C}-1)$ [26, 29]. The 12 selected genotypes represented six individuals each from the $\mathrm{C}+3$ and $\mathrm{C}-1$ populations. Within each population, three genotypes with high-stem lignin and three genotypes with low-stem lignin were selected for further analyses.

Individual plants were grown in a space-planted $(1.1 \mathrm{~m})$ field nursery near Mead, NE, and cultivated as needed. Plants were harvested after the first killing frost (November 10, 2005) by cutting tillers $4 \mathrm{~cm}$ above soil level. Tillers containing leaves and reproductive structures were oven-dried at $50{ }^{\circ} \mathrm{C}$ for $48 \mathrm{~h}$ and ground to pass through $1-\mathrm{mm}$ screens. Ground plant materials were used for all subsequent analyses.

\section{Chemical Analyses}

Above-ground portions of whole plants were chopped, ground in a Wiley Mill through a ten-mesh screen, and reground in a Wiley Mill through a 20-mesh screen. Samples of untreated fractions and pretreated residues of these switchgrass genotypes (described later) were freeze-dried and ground in a SPEX 5100 Mixer Mill (SPEX Industries, Inc., Metuchen, NJ, USA) before chemical analysis. Fractions were treated with $4 \mathrm{M} \mathrm{NaOH}$, in the absence of nitrobenzene, at $170{ }^{\circ} \mathrm{C}$ for $2 \mathrm{~h}$ to release a variety of mono- or dimethoxylated aromatic compounds. The aromatic compounds, including phenolic acids, were measured as their silyl ethers using $N$,O, bis(trimethylsilys)trifloroacetamide by gasliquid chromatography as previously described [30]. The amounts of compounds of similar structure were summed to provide estimates of guaiacyl (coniferyl) or syringyl lignin as follows: guaiacyl—vanillin, acetovanillone, and vanillic acid; syringyl—syringaldehyde, acetosyringone, and syringic acid. Ester-linked and total $p$-coumaric $(p \mathrm{CA})$ and ferulic acids (FA) were determined by treatment of freeze-dried ground material with (a) $2 \mathrm{M}$ $\mathrm{NaOH}$ at room temperature for $24 \mathrm{~h}$ or (b) $4 \mathrm{M} \mathrm{NaOH}$ at $170^{\circ} \mathrm{C}$ for $2 \mathrm{~h}$, respectively.

\section{Cellulase Degradation of Switchgrass Genotypes}

Cellulase (EC 3.2.1.4, catalog no. C-8546, Sigma Chemical Co., St. Louis, MO, USA) was used to evaluate and rank the biodegradation of various genotypes [31]. The cellulase was added to $50 \mathrm{mM}$ sodium acetate buffer, $\mathrm{pH} 5.0$, to give an activity of $20 \mathrm{U} / \mathrm{ml}$ ( $192.3 \mathrm{~g} / 100 \mathrm{ml}$ buffer). Twenty milliliters of enzyme solution was added to $0.5 \mathrm{~g}$ of freezedried switchgrass material, which had been ground in a Wiley Mill as described above. Samples were incubated at $37{ }^{\circ} \mathrm{C}$ for $72 \mathrm{~h}$ unless otherwise indicated. Afterward, the tubes 
were centrifuged, the liquid decanted, and the residue freeze-dried and weighed. Dry weight loss was calculated as follows: $1-($ residual weight/starting weight $) \times 100$.

\section{Pretreatment of Switchgrass Genotypes with Esterases before Cellulase Hydrolysis}

Switchgrass samples were freeze-dried, and $0.5 \mathrm{~g}$ samples were used in triplicate for each test with esterase as described [31]. Samples were treated with the commercial product Depol $740 \mathrm{~L}$, which is one of a range of ferulic acid esterase (FAE)-containing enzymes from Biocatalysts Ltd. (Pontypridd, UK). Depol 740 L reportedly removes free phenolic acids from plant material and increases amounts of fermentable sugars. We did not evaluate other enzyme activities present in Depol $740 \mathrm{~L}$; conceivably, this esterase preparation contained other glucanases. However, we have not discriminated between the effects due to esterase activity, relative to those of contaminating glucanases. Our assumption was that biomass, first challenged with an esterase preparation subsequently followed by cellulase, would provide insights into phenolic (ferulic) acid ester-related accessibility of cell walls relative to the cellulase treatment by itself. Our data indicates that there was release of sugars from biomass samples treated with Depol 750 L. Typical FAE activity for Depol $740 \mathrm{~L}$ is $36 \mathrm{U} / \mathrm{g}$ (product information from Biocatalysts Ltd.). Esterase was used in high amounts, i.e., $1 \mathrm{~g}$ mixture [26] for each $0.5 \mathrm{~g}$ switchgrass sample, to ensure maximal loss of ester-linked aromatic acids. Each sample was mixed with $20 \mathrm{ml}$ of $50 \mathrm{mM}$ sodium acetate buffer, pH 5.0, containing $1.0 \mathrm{~g}$ of Depol $740 \mathrm{~L}$, mixed for $5 \mathrm{~s}$, and incubated at $37{ }^{\circ} \mathrm{C}$ for $24 \mathrm{~h}$ in a reciprocal water bath at about 100 back and forth strokes per minute. After incubation with esterases, tubes were centrifuged at $730 \times \mathrm{g}$ for $2 \mathrm{~min}$ and the liquid decanted. The samples were washed by adding $20 \mathrm{ml}$ distilled water to the pellet, vortexed for $5 \mathrm{~s}$, centrifuged, and the liquid decanted. Decanted liquids, enzyme mixture and washings, were analyzed for phenolic acids and for sugars. The esterase-treated, washed residues were subsequently incubated as above with cellulase (described above) or freezedried and weight loss calculated before subsequent incubation with cellulase. Dry weight loss was calculated as described above.

Aromatic compounds, i.e., acetovanillin and vanillic, ferulic, and $p$-coumaric acids, and free monosaccharides in the decanted liquids from the pretreatments were analyzed as their silyl ethers and measured by gas-liquid chromatography as described [32]. No further treatments were performed on these liquid samples to analyze disaccharides and larger polymers released as a result of enzymatic treatments of samples. The concentrations of aromatic constituents were analyzed for differences using PROC MIXED in SAS [33] and are presented as milligram per gram amounts of the starting weights of freeze-dried, ground fractions.

\section{Results}

The overall population means for DMD and stem lignin were similar to those reported previously $[24,26]$ and are reported herein to confirm the genetic stability of lignin concentration in switchgrass biomass over environments. For the $\mathrm{C}-1$ plants (bred for one cycle for low digestibility), DMD and stem lignin were $46.4 \%$ and $9.1 \%$, respectively, and were significantly different $(P \leq 0.01)$ than the population means for the $\mathrm{C}+3$ plants (bred for three cycles for high digestibility), which were $50.2 \%$ for DMD and $8.0 \%$ for stem lignin [29].

A comparison of the DMD of the 12 genotypes relative to their overall stem lignin content is shown in Fig. 1. Stem lignin concentration was highly correlated to DMD $\left(r^{2}=\right.$ 
Fig. 1 Relationship between DMD and lignin for the twelve switchgrass genotypes. Open triangle $\mathrm{C}-1$ population, low $\mathrm{DMD}$; filled triangle $\mathrm{C}+3$ population, low DMD; open circle $\mathrm{C}-1$ population, high $\mathrm{DMD}$; filled circle $\mathrm{C}+3$ population, high DMD

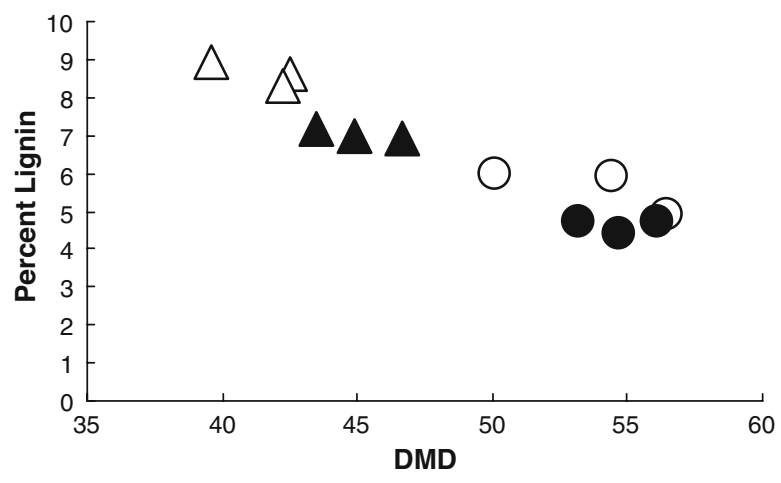

0.91) among the evaluated plants. For the three high-lignin genotypes from the $\mathrm{C}-1$ population $(7,10$, and 12 , open triangles), the mean DMD was $41.4 \%$ as compared to $53.6 \%$ DMD for the low-lignin genotypes $(4,5$, and 11, open circles) in this population. Similarly for three plants from the $\mathrm{C}+3$ population, the genotypes with high lignin $(1,3$, and 6 , filled triangles) had a mean digestibility of $45.0 \%$ as compared to $54.7 \%$ for the three genotypes $(2,8$, and 9 , filled circles) with low-stem lignin.

Although stem lignin was strongly correlated to DMD, there was noticeable variation between genotypes for these traits (Fig. 1), suggesting that differences in the types and amount of phenolics could be underlying factors for these observations.

To assess differences in the aromatic constituents, plant samples were subjected to alkali hydrolysis followed by gas chromatographic determination of $p \mathrm{CA}$ and FA as their silyl esters. In addition, the relative concentrations of G- and S-lignin were also evaluated (Table 1).

Ester-linked phenolics released by mild alkali treatment differed by genotype within populations. Concentrations of $p C A$ ranged from $6.4 \mathrm{mg}$ to $10.7 \mathrm{mg} \mathrm{g}^{-1}$ dry matter for $p \mathrm{CA}$ $(P=0.0047$; Table 1). For example, genotypes 5 and 11 from the $\mathrm{C}-1$ population had significantly greater amounts of $p \mathrm{CA}$ in ester-linkages as compared to the other genotypes across the two populations. In the plants from the $\mathrm{C}+3$ population, genotype 1 displayed lowest $p \mathrm{CA}$ levels in ester-linkages. As a general trend, plants in the $\mathrm{C}-1$ population with higher DMD (genotypes 4, 5, and 11) exhibited higher ester-linked $p C A$ content as compared to the genotypes from the $\mathrm{C}+3$ population. These results are consistent with the results of Gabrielsen et al. [23] who analyzed bulk pasture samples of $\mathrm{C}-1$ and $\mathrm{C}+1$ (firstgeneration bred for high DMD) populations from the same switchgrass breeding population. FA in ester-linkages varied from a low of $1.6 \mathrm{mg} \mathrm{g}^{-1}$ dry matter to a high of $3.1 \mathrm{mg} \mathrm{g}^{-1}$ dry matter (Table $1 ; P=0.0022$ ). The greatest variation in FA content was observed for genotypes from either the $\mathrm{C}-1$ or the $\mathrm{C}+3$ population selected for high DMD with the broadest range in the $\mathrm{C}+3$ population (genotypes 2,8 , and 9). In contrast, genotypes in the $\mathrm{C}^{-1}$ population $(7,10$, and 12) with low DMD consistently displayed lower levels of FA in ester-linkages $\left(<2.0 \mathrm{mg} \mathrm{g}^{-1}\right.$ dry matter). In the $\mathrm{C}+3$ population, genotypes $(1,3$, and 6) with low DMD exhibited relatively similar levels of FA (about $2.1 \mathrm{mg} \mathrm{FA} \mathrm{g}^{-1}$ dry matter).

Total (i.e., ester- and ether-linked) $p \mathrm{CA}$ levels were higher than ester-linked $p \mathrm{CA}$ only for the three genotypes from the $\mathrm{C}-1$ population selected for low DMD. Levels of total $p \mathrm{CA}$ in the other genotypes analyzed were generally similar to the values observed for ester-linked $p C A$. Much larger amounts of total FA were released by $4.0 \mathrm{M} \mathrm{NaOH}$ treatment 


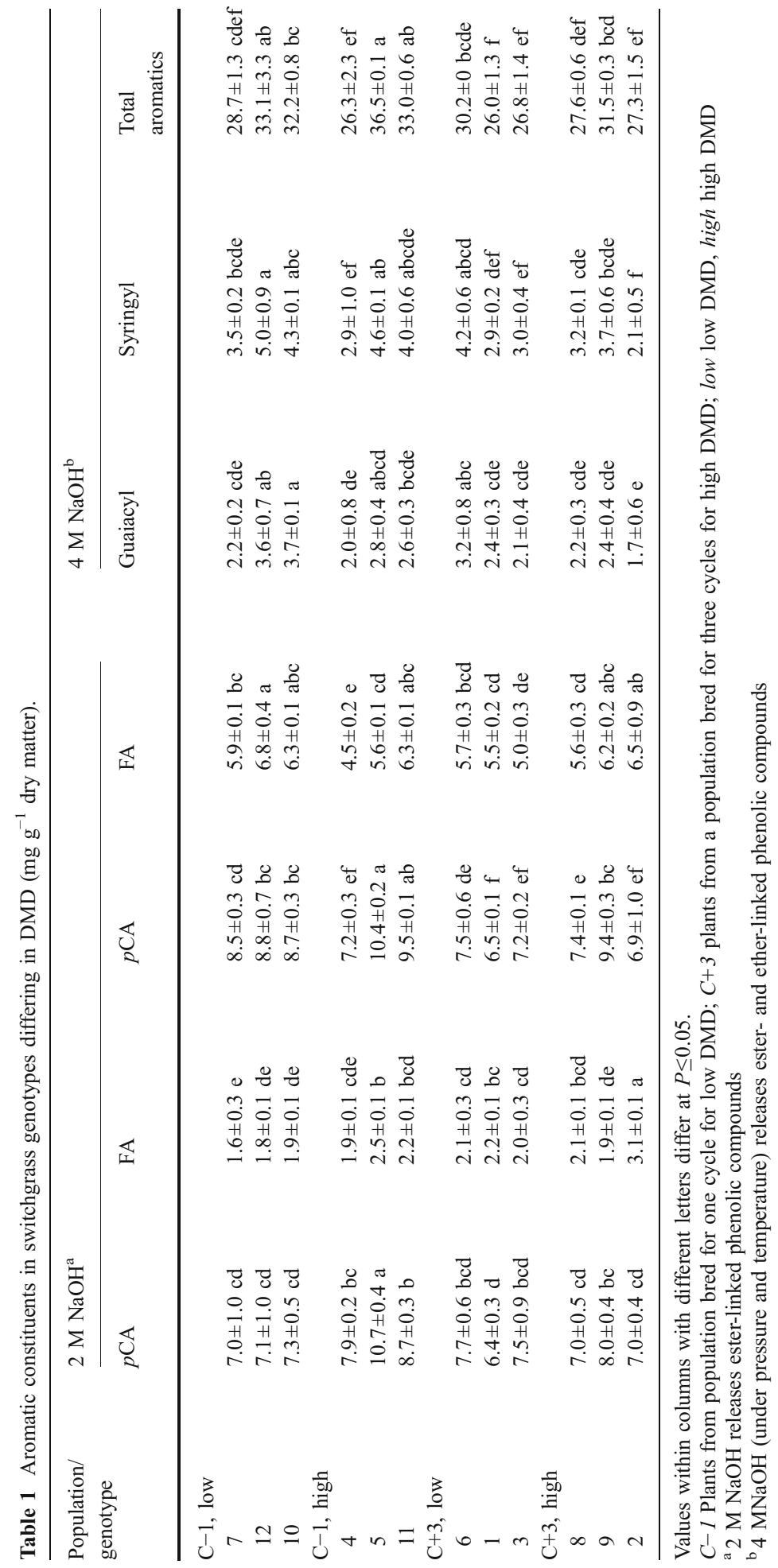


for all the genotypes, compared to that released by $2.0 \mathrm{M} \mathrm{NaOH}$. This result indicates that a higher proportion of FA exists in ether than ester bonds. These ratios (FA 4.0 M NaOH/FA $2.0 \mathrm{M} \mathrm{NaOH}$ ) ranged from approximately 2.1 for genotype 2 to a high of 3.7 for genotypes 7, 12, and 10 from the $\mathrm{C}-1$ population (Table 1 ).

Guaiacyl-lignin in these plants ranged from a low value of $1.7 \mathrm{mg} \mathrm{g}^{-1}$ dry matter for genotype 2 in the $\mathrm{C}+3$ population to a high of $3.7 \mathrm{mg} \mathrm{g}^{-1}$ dry matter for genotype 10 in the $\mathrm{C}-1$ population. A general trend in these analyses indicated that there was less variation in guaiacyl-lignin in plants from the $\mathrm{C}+3$ population as compared to the $\mathrm{C}-1$ population (Table 1).

Syringyl-lignin values varied by genotype $(P=0.0462)$ and ranged from a high of $5.0 \mathrm{mg} \mathrm{g}^{-1}$ dry matter for genotype $12\left(\mathrm{C}-1\right.$ population, low DMD) to a low of $2.1 \mathrm{mg} \mathrm{g}^{-1}$ dry matter for genotype 2 (high DMD) from the $\mathrm{C}+3$ population (Table 1). As a trend, plants from the $\mathrm{C}+3$ population exhibited lower S-lignin than plants from the $\mathrm{C}-1$ population. Combined values of $\mathrm{G}+\mathrm{S}$-lignin were consistently higher in genotypes from the $\mathrm{C}-1$ population as compared to the genotypes from the $\mathrm{C}+3$ population. For example, low DMD genotypes 7,10 , and 12 from the $\mathrm{C}-1$ population had $\mathrm{S}$-lignin values of $3.5,4.3$, and $5.0 \mathrm{mg} \mathrm{g}^{-1}$ dry matter, respectively, as compared to S-lignin values below 4.2 and $3.7 \mathrm{mg}^{-1}$ dry matter in the three low and high DMD genotypes from the $\mathrm{C}+3$ population, respectively.

Higher levels of total aromatics were observed in genotypes from the $\mathrm{C}-1$ population as compared to the plants from the $\mathrm{C}+3$ population $(P=0.0011)$. Genotypes 5,11 , and 12 from the $\mathrm{C}-1$ population had significantly higher amounts of total aromatics as compared to the other plants analyzed. Plant 1 with the lowest total aromatics was in the $\mathrm{C}+3$ population bred for higher DMD. However, there appeared to be significant variation in aromatic content between these plants, which suggested that other properties of the cell walls may have been altered as well.

Using a combination of FAE and cellulase (C) treatments, we probed the possible architecture of cells walls in these genotypes.

For all genotypes in the $\mathrm{C}-1$ population, buffer $(\mathrm{B})$ treatment alone released $p \mathrm{CA}$. Buffer treatment released low amounts of FA in four genotypes (Table 2). In contrast, for plants from the $\mathrm{C}+3$ population, buffer treatment released FA in two of these plants (genotypes 2 and 6). Treatment with FAE resulted in a significant release of phenolic acids, principally as $p \mathrm{CA}$ followed by FA. Interestingly, low levels of acetovanillone and vanillic acid were recovered from most genotypes after esterase treatment (data not shown); however, the ratio of acetovanillone + vanillic acid/pCA + FA ranged from a high of $23 \%$ in genotype $12(\mathrm{C}-1$ population) to a low of $11 \%$ (genotypes 5 and $11, \mathrm{C}-1$ population). Less variation in this ratio was observed for the six genotypes from the $\mathrm{C}+3$ population, which ranged from a high of $15 \%$ for genotypes 1 and 3 to $12 \%$ for genotype 8 . For the two dominant phenolic acids released by FAE, there was significant variation both in the total amounts of $p$ CA and FA released as well as in their ratio among the genotypes. As an example, for genotypes in the $\mathrm{C}-1$ population, the ratio of $\mathrm{pCA} / \mathrm{FA}$ released by FAE ranged from 3.1 for genotype 4 to a low of 1.4 for genotype 5 . For the plants from the $\mathrm{C}+3$ population the ratio of $p \mathrm{CA} / \mathrm{FA}$ did not exceed 2.5 (genotype 9) with the other genotypes exhibiting a ratio below 2.0. The lowest observed value was 0.96 for genotype 1 (Table 2).

Treatment of the post-FAE residue with cellulase elicited a further release of $p \mathrm{CA}$ and FA. Further release of acetovanillone and vanillic acid was not observed for any of the genotypes. The amounts of phenolic acids recovered varied significantly between genotypes and populations. Cellulase treatment released amounts of $p \mathrm{CA}$ equal or similar to that by FAE digestion, but levels of FA released by subsequent cellulase treatment were 
Table $2 p$-Coumaric acid and ferulic acid released into filtrate by esterase and cellulase from switchgrass genotypes.

\begin{tabular}{|c|c|c|c|}
\hline \multirow{3}{*}{$\begin{array}{l}\text { Population; } \\
\text { genotype }\end{array}$} & \multirow[t]{3}{*}{ Treatment $^{\mathrm{a}}$} & \multicolumn{2}{|l|}{ Phenolic acids } \\
\hline & & \multicolumn{2}{|l|}{$\mathrm{mg} \mathrm{g}^{-1}$ dry matter } \\
\hline & & $p$-Coumaric acid & Ferulic acid \\
\hline \multirow[t]{4}{*}{$\mathrm{C}-1 \mathrm{~L} ; 7$} & $\mathrm{~B}$ & $0.072 \pm 0.006 \mathrm{~d}$ & $0 \mathrm{~d}$ \\
\hline & $\mathrm{E}$ & $0.232 \pm 0.008 \mathrm{a}$ & $0.108 \pm 0.007 \mathrm{a}$ \\
\hline & then $\mathrm{C}$ & $0.182 \pm 0.002 \mathrm{~b}$ & $0.035 \pm 0.002 \mathrm{~b}$ \\
\hline & $\mathrm{C}$ & $0.099 \pm 0.018 \mathrm{c}$ & $0.027 \pm 0.024 \mathrm{c}$ \\
\hline \multirow[t]{4}{*}{$\mathrm{C}-1 \mathrm{~L} ; 12$} & B & $0.066 \pm 0.003 \mathrm{c}$ & $0 \mathrm{c}$ \\
\hline & $\mathrm{E}$ & $0.107 \pm 0.001 \mathrm{~b}$ & $.056 \pm .005 \mathrm{a}$ \\
\hline & then $\mathrm{C}$ & $0.138 \pm 0.002 \mathrm{a}$ & $.023 \pm .001 \mathrm{~b}$ \\
\hline & $\mathrm{C}$ & $0.062 \pm 0.009 \mathrm{c}$ & $0 \mathrm{c}$ \\
\hline \multirow[t]{4}{*}{$\mathrm{C}-1 \mathrm{~L} ; 10$} & $\mathrm{~B}$ & $0.046 \pm 0.003 \mathrm{c}$ & $0 \mathrm{~d}$ \\
\hline & $\mathrm{E}$ & $0.145 \pm 0.008 \mathrm{~b}$ & $.058 \pm .003 \mathrm{a}$ \\
\hline & then $\mathrm{C}$ & $0.176 \pm 0.023 \mathrm{a}$ & $.032 \pm .003 \mathrm{~b}$ \\
\hline & $\mathrm{C}$ & $0.048 \pm 0.025 \mathrm{c}$ & $.014 \pm .012 \mathrm{c}$ \\
\hline \multirow[t]{4}{*}{$\mathrm{C}-1 \mathrm{H} ; 4$} & B & $0.060 \pm 0.017 \mathrm{~b}$ & $.006 \pm .005 \mathrm{c}$ \\
\hline & $\mathrm{E}$ & $0.191 \pm 0.001 \mathrm{a}$ & $.062 \pm .014 \mathrm{a}$ \\
\hline & then $\mathrm{C}$ & $0.168 \pm 0.007 \mathrm{a}$ & $.028 \pm .005 \mathrm{~b}$ \\
\hline & $\mathrm{C}$ & $0.087 \pm 0.006 \mathrm{~b}$ & $.026 \pm .001 \mathrm{~b}$ \\
\hline \multirow[t]{4}{*}{$\mathrm{C}-1 \mathrm{H} ; 5$} & B & $0.081 \pm 0.026 \mathrm{~d}$ & $0 \mathrm{c}$ \\
\hline & $\mathrm{E}$ & $0.324 \pm 0.005 \mathrm{a}$ & $.236 \pm .003 \mathrm{a}$ \\
\hline & then $\mathrm{C}$ & $0.240 \pm 0.010 \mathrm{~b}$ & $.051 \pm .002 \mathrm{~b}$ \\
\hline & $\mathrm{C}$ & $0.117 \pm 0.010 \mathrm{c}$ & $.009 \pm .001 \mathrm{c}$ \\
\hline \multirow[t]{4}{*}{$\mathrm{C}-1 \mathrm{H} ; 11$} & $\mathrm{~B}$ & $0.066 \pm 0.006 \mathrm{c}$ & $.007 \pm .001 \mathrm{c}$ \\
\hline & $\mathrm{E}$ & $0.176 \pm 0.010 \mathrm{~b}$ & $.106 \pm .008 \mathrm{a}$ \\
\hline & then $\mathrm{C}$ & $0.235 \pm 0.028 \mathrm{a}$ & $.044 \pm .004 \mathrm{~b}$ \\
\hline & $\mathrm{C}$ & $0.089 \pm 0.008 \mathrm{c}$ & $.015 \pm .003 \mathrm{c}$ \\
\hline \multirow[t]{4}{*}{$\mathrm{C}+3 \mathrm{~L} ; 6$} & B & $0.077 \pm 0.011 \mathrm{c}$ & $.003 \pm .006 \mathrm{c}$ \\
\hline & $\mathrm{E}$ & $0.252 \pm 0.012 \mathrm{a}$ & $.137 \pm .008 \mathrm{a}$ \\
\hline & then $\mathrm{C}$ & $0.194 \pm 0.017 \mathrm{~b}$ & $.044 \pm .012 \mathrm{~b}$ \\
\hline & $\mathrm{C}$ & $0.077 \pm 0.041 \mathrm{c}$ & $.011 \pm .019 \mathrm{c}$ \\
\hline \multirow[t]{4}{*}{$\mathrm{C}+3 \mathrm{~L} ; 1$} & $\mathrm{~B}$ & $0.065 \pm 0.004 \mathrm{~b}$ & $0 \mathrm{c}$ \\
\hline & $\mathrm{E}$ & $0.174 \pm 0.004 \mathrm{a}$ & $.183 \pm .004 \mathrm{a}$ \\
\hline & then $\mathrm{C}$ & $0.175 \pm 0.014 \mathrm{a}$ & $.061 \pm .004 \mathrm{~b}$ \\
\hline & $\mathrm{C}$ & $0.074 \pm 0.012 \mathrm{~b}$ & $0 \mathrm{c}$ \\
\hline \multirow[t]{4}{*}{$\mathrm{C}+3 \mathrm{~L} ; 3$} & $\mathrm{~B}$ & $0.077 \pm 0.001 \mathrm{c}$ & $0 \mathrm{c}$ \\
\hline & $\mathrm{E}$ & $0.206 \pm 0.019 \mathrm{a}$ & $.114 \pm .011 \mathrm{a}$ \\
\hline & then $\mathrm{C}$ & $0.172 \pm 0.005 \mathrm{c}$ & $.037 \pm .001 \mathrm{~b}$ \\
\hline & $\mathrm{C}$ & $0.093 \pm 0.002 \mathrm{c}$ & $0 \mathrm{c}$ \\
\hline \multirow[t]{4}{*}{$\mathrm{C}+3 \mathrm{H} ; 8$} & B & $0.074 \pm 0.004 \mathrm{c}$ & $.008 \pm .007 \mathrm{~d}$ \\
\hline & $\mathrm{E}$ & $0.281 \pm 0.004 \mathrm{a}$ & $.195 \pm .008 \mathrm{a}$ \\
\hline & then $\mathrm{C}$ & $0.199 \pm 0.006 \mathrm{~b}$ & $.059 \pm .002 \mathrm{~b}$ \\
\hline & $\mathrm{C}$ & $0.092 \pm 0.059 \mathrm{c}$ & $.027 \pm .008 \mathrm{c}$ \\
\hline \multirow[t]{4}{*}{$\mathrm{C}+3 \mathrm{H} ; 9$} & $\mathrm{~B}$ & $0.067 \pm 0.013 \mathrm{c}$ & $0 \mathrm{~b}$ \\
\hline & $\mathrm{E}$ & $0.142 \pm 0.069 \mathrm{~b}$ & $.057 \pm .031 \mathrm{a}$ \\
\hline & then $\mathrm{C}$ & $0.246 \pm 0.024 \mathrm{a}$ & $.059 \pm .005 \mathrm{a}$ \\
\hline & $\mathrm{C}$ & $0.050 \pm 0.064 \mathrm{c}$ & $.023 \pm .023 \mathrm{ab}$ \\
\hline \multirow[t]{2}{*}{$\mathrm{C}+3 \mathrm{H} ; 2$} & $\mathrm{~B}$ & $0.088 \pm 0.005 \mathrm{c}$ & $.006 \pm .011 \mathrm{c}$ \\
\hline & $\mathrm{E}$ & $0.209 \pm 0.011 \mathrm{a}$ & $.189 \pm .011 \mathrm{a}$ \\
\hline
\end{tabular}


Table 2 (continued).

\begin{tabular}{llll}
\hline $\begin{array}{l}\text { Population; } \\
\text { genotype }\end{array}$ & Treatment $^{\mathrm{a}}$ & Phenolic acids & \\
\cline { 2 - 3 } & & $\mathrm{mg} \mathrm{g}^{-1} \mathrm{dry}$ matter & Ferulic acid \\
\cline { 2 - 3 } & & $p$-Coumaric acid & $.089 \pm .007 \mathrm{~b}$ \\
then C & $0.190 \pm 0.013 \mathrm{~b}$ & $.008 \pm .014 \mathrm{c}$ \\
\hline
\end{tabular}

Population $\mathrm{C}-1$ and $\mathrm{C}+3 \mathrm{~L}$ and $\mathrm{H}$ ( $L$ low DMD; $H$ High DMD). Values for different treatments within a genotype with different letters differ at $P \leq 0.05$.

${ }^{\mathrm{a}} B$ Buffer only; $E$ ferulic acid esterase; then $C$ cellulase treatment of washed esterase residue; $C$ cellulase only

considerably less than those released by FAE digestion. Interestingly, the ratios of $p \mathrm{CA} / \mathrm{FA}$ in the post-FAE cellulase treatment were 4.7 to 6 in the genotypes from the $C-1$ population and 2.1 to 4.6 in the genotypes from the $\mathrm{C}+3$ population (Table 2).

Direct cellulase treatment of plant tissues released trace amounts of acetovanillone and vanillic acid from some of the genotypes from both the $\mathrm{C}-1$ and $\mathrm{C}+3$ populations and significantly greater amounts of $p \mathrm{CA}$ and FA. For all genotypes tested, the amounts of aromatics released into the digestion medium was less than the amounts detected by incubation of tissues with FAE or FAE followed by cellulase (Table 2).

Xylose (Xyl) and glucose (Glc) released by enzymatic treatments of tissues were also analyzed (Fig. 2a,b). Incubating tissues in buffer alone released trace amounts of arabinose, rhamnose, and Xyl from only genotypes 5 and 12 from the $\mathrm{C}-1$ population and from genotype 2 of the $\mathrm{C}+3$ population. Small levels of hexoses, Glc, galactose, and mannose were detected after incubating tissues in buffer alone for all genotypes, except for genotypes 2 and 5, which showed substantial release of Glc. Treating tissues with FAE enhanced release of both pentoses and hexoses with significant differences in the amounts detected between the genotypes. As a general trend, FAE elicited a relatively modest release of arabinose in all genotypes, with maximal release from genotypes 3,8 , and 9 from the $\mathrm{C}+3$ population and genotype 11 from the $\mathrm{C}-1$ population (data not shown). Amounts of rhamnose released into the FAE incubation media was low for four out of six genotypes in the $\mathrm{C}-1$ population, with none detected for genotypes 4 and 12 . In contrast, four of six genotypes in the $\mathrm{C}+3$ population contained significant levels of FAE-accessible rhamnose. Moderate amounts of Xyl (Fig. 2a) was released upon FAE treatments in all genotypes, with a range from $11.7 \mathrm{mg} \mathrm{g}^{-1}$ dry matter for genotype 9 from the $\mathrm{C}+3$ population to a low of $1.4 \mathrm{mg} \mathrm{g}^{-1}$ dry matter for genotype 12 of the $\mathrm{C}-1$ population.

Significant release of Glc occurred in response to FAE treatment. This ranged from a high of $65.1 \mathrm{mg} \mathrm{g}^{-1}$ dry matter in genotype $9\left(\mathrm{C}+3\right.$ population) to a low of $16.1 \mathrm{mg} \mathrm{g}^{-1}$ dry matter in genotypes 1 ( $\mathrm{C}+3$ population) and genotype $7(\mathrm{C}-1$ population). Fungal contamination was observed in some tubes having considerably wide variations (repeat analyses) in glucose content in the supernatant, suggesting variable loss of glucose. Therefore, some of the values for glucose may be underrepresented. The amounts of Gal and Man released were quite modest.

Incubation of FAE-treated plant residue with cellulase had minimal effect on arabinose and rhamnose released as compared to FAE treatment by itself. Levels of Xyl liberated by this treatment were comparable to the amounts released by FAE alone (Fig. 2a). A similar trend was observed for glucose (Fig. 2b). 
Fig. 2 Release of xylose (a) and glucose (b) (mg sugar released/g dry matter $\pm \mathrm{SD}$ ) for plant tissues incubated with FAE ( $E$; gray bars), followed by cellulase (then $C$; black bars) or with cellulase alone ( $C$; striped bars). The bars below groups of three genotypes indicate their population and DMD class (high or low)
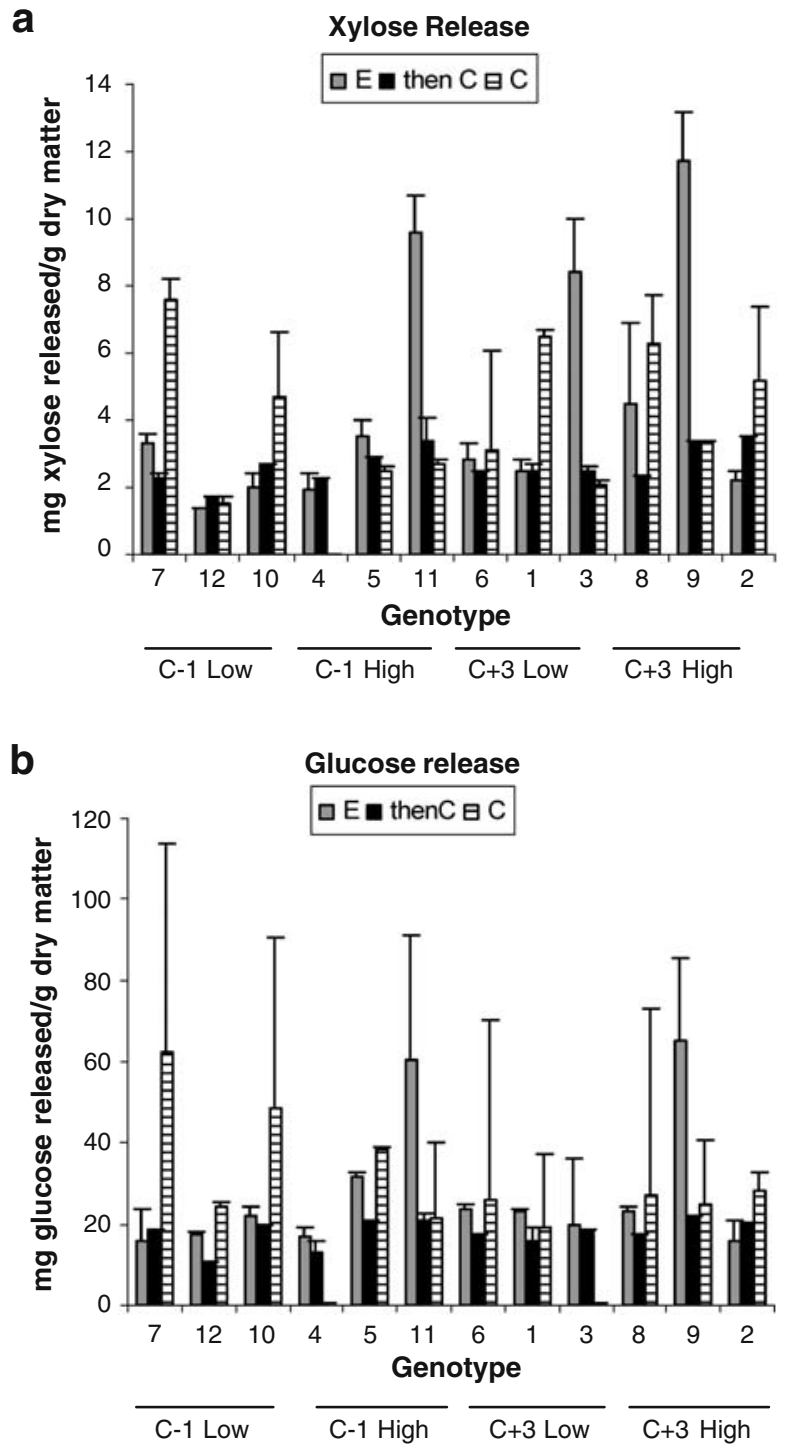

When plant tissues were directly incubated in cellulase, there was much greater variation in the profiles of released pentoses and hexoses (Fig. 2a,b). For genotypes 7 and 10 of the $\mathrm{C}-1$ population, cellulase by itself released significantly greater amounts of $\mathrm{Xyl}$ and Glc as compared to the sequential treatment of FAE followed by cellulase, a trend not observed for the six genotypes from the $\mathrm{C}+3$ population. In these genotypes, cellulase treatment liberated much lower amounts of Glc as compared to a combined treatment of FAE and cellulase (Fig. 2a,b).

Dry weight loss (DWL) of plant samples after enzymatic digests were evaluated to obtain an estimate of cell-wall structure (Fig. 3). Across all genotypes, cellulase treatment alone resulted in lower dry matter loss as compared to a combined treatment with FAE followed by cellulase. As a trend, genotypes in the $\mathrm{C}-1$ population exhibited lower DWL as 
Fig. 3 Percent dry weight loss $( \pm \mathrm{SD})$ for plant tissues incubated with cellulase $(C$; open bars) or after incubation with FAE + cellulase $(\mathrm{E}+\mathrm{C}$; gray bars). The bars below groups of three genotypes indicate their population and DMD class (high or low)

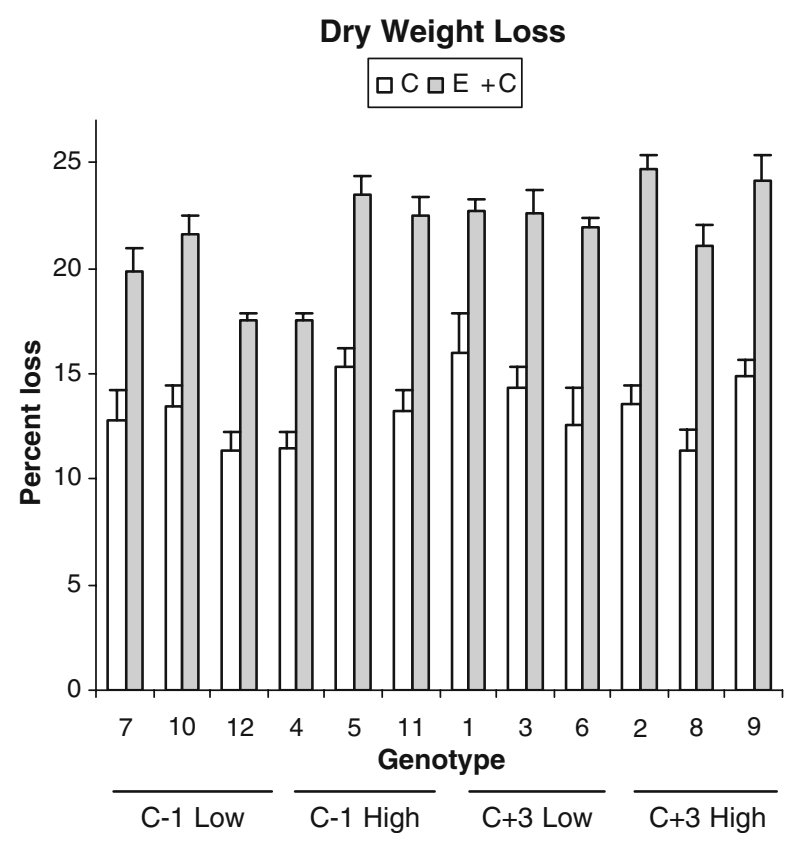

compared to the genotypes in the $\mathrm{C}+3$ population: $12.9 \%$ vs $13.8 \%$ DWL, respectively, after cellulase treatment and $20.4 \%$ vs $22.9 \%$ after FAE + cellulase treatment, respectively. When DWL was expressed as a difference between the two enzymatic treatments [DWL in (FAE+cellulase)-cellulase alone], variations in the genotypes based on DMD were observed. For these plants, the average differences in DWL were 7.1, 7.8, 8.1, and 10.8 for the low and high DMD genotypes within the $\mathrm{C}-1$ and the $\mathrm{C}+3$ population, respectively (Fig. 3).

\section{Discussion}

For plants selected in this study, DMD was negatively correlated with lignin (Fig. 1, also see [29]) indicating that cell-wall composition and possibly architecture were altered due to selection. Cell-wall composition is a complex trait controlled through the actions of many genes [34-37], and it is likely that genotypes with altered lignin and DMD could arise from several different combinations of genes. Furthermore, lignin is a mixed polymer, composed of different aromatic compounds cross-linked to each other and to cell-wall carbohydrates [36-39]. Thus, both the total lignin content and the extent of cross-linking will impact the DMD of plant tissues and influence the utility of specific genotypes as biofuel feedstocks.

The range of exploitable diversity in cell-wall components observed for the switchgrass plants selected from the two populations divergently bred for DMD was striking. The type of linkages of various aromatic compounds determined by their response to alkali treatments (Table 2) varied significantly among the genotypes. For all plants, amounts of ester-linked $p \mathrm{CA}$ was higher than ester-linked FA, with the $p \mathrm{CA} / \mathrm{FA}$ ratio averaging $3.7 \pm$ 0.6 . For the genotypes, the ratio of $p \mathrm{CA} / \mathrm{FA}$ was greater $(P \leq 0.05)$ for the $\mathrm{C}-1$ population over the $\mathrm{C}+3$ population, although amounts of $p \mathrm{CA}$ and $\mathrm{FA}$ did not differ between populations. These data indicate that levels of both $p \mathrm{CA}$ and FA had been significantly 
altered through selection for DMD at the whole plant level, suggesting the potential to selectively breed for each phenolic acid. In other grass species, breeding for improved digestibility is often accompanied by changes in lignin and levels of and linkages of phenolics [40, 41].

The phenolic acids released by $4 \mathrm{M} \mathrm{NaOH}$ under pressure and temperature in the absence of nitrobenzene, and determined as their silyl esters, gave an estimate of the total amounts of $p \mathrm{CA}$ and FA, i.e., both ester- and ether-linked. The ratio of $p \mathrm{CA}$ released by $4 \mathrm{M} \mathrm{NaOH} / 2 \mathrm{M} \mathrm{NaOH}$ was $1.06 \pm 0.1$, indicating that most of the $p C A$ was ester-linked. In contrast, this ratio for FA was $2.8 \pm 0.5$, indicating that ether-linked FA was substantially greater than ester-linked FA. Within the high- and low-lignin groups within populations, the ratio of $4 \mathrm{M} \mathrm{NaOH} / 2 \mathrm{M} \mathrm{NaOH}$ was significantly greater $(P \leq 0.05)$ for $p \mathrm{CA}$ and FA for the high-lignin genotypes in the $\mathrm{C}+1$ population over all the other genotypes. Total aromatics for all genotypes averaged $29.9 \pm 3.3 \mathrm{mg}$ aromatics per gram of dry matter. Differences did not occur between populations in total aromatics or in the $\mathrm{G} / \mathrm{S}$ ratio. These data indicated considerable variation among aromatic types and linkages, but no clear-cut differences occurred among high- and low-lignin types. This result suggests that factors leading to variations in DMD are complex and not related to a single linkage type of aromatic. It has been observed that ferulate primarily cross-linked to arabinoxylans is a limiting factor in digestibility for many forage species (for example, [21, 42]. Ferulate cross-linking is expected to be catalyzed by wall-bound peroxidases [43] and changes with developmental maturity in grass stems and leaves [42, 44, 45]. Divergent breeding for DMD in switchgrass leads to significant alteration in tiller anatomy in plants from the two populations [46] and appears to have differentially affected pathways impacting cell-wall compositions in these genotypes as well. Conceivably, similar changes in enzyme activity within plants could lead to diverse changes in phenolic composition and linkages to arabinoxylans depending on the population background.

Treatment with FAE and cellulase resulted in release of different amounts of aromatic compounds from the genotypes (Table 2). The most prevalent aromatic compounds in filtrates were $p \mathrm{CA}$ and FA. In other grasses analyzed by similar methods, $p \mathrm{CA}$ was released in far greater amounts than FA in all genotypes (Akin, unpublished data). Release of $p \mathrm{CA}$ was often greater with FAE than subsequent treatment with cellulase; in some genotypes, however, release of $p \mathrm{CA}$ was greater in the subsequent cellulase treatment. A similar situation occurred with FA, although much less was released compared with $p \mathrm{CA}$. These data provide further indications that application of DMD as the sole selection pressure can lead to differential, even contradictory effects at the cell-wall level in switchgrass population. However, they highlight the phenotypic plasticity coded by the switchgrass genome and suggest that combining DMD with other more specific cell-wall traits could result in switchgrass genotypes with greater utility as bioenergy feedstocks.

Sugars released by FAE and cellulase treatments included arabinose, rhamnose, Xyl, Glc, galactose, and mannose. Glc was the most prevalent, followed by Xyl (Fig. 2a,b). In most cases, FAE released greater amounts of Glc and Xyl over those released during subsequent cellulase treatment, although some exceptions occurred. Due to apparent microbial activity during incubation, the amounts of Glc varied consistently (i.e., repeat analyses) within individual vessels, therefore resulting in large variations for some genotypes. Unlike the phenolic acids, usually cellulase alone released greater amounts of Glc and Xyl than cellulase after FAE treatment. These data suggest that glucanase activities were present in the FAE preparations, which resulted in partial digestion of both hemicellulose and cellulose. Interestingly, the combination of FAE followed by cellulase always released the greatest amounts of free sugars from the samples, suggesting that FAE 
present in Depol 740 L improved glucanase accessibility to switchgrass cell walls. Assuming that cellulose makes up about $30 \%$ of the dry matter in switchgrass samples [6], yields of total glucose for the plants evaluated in this study ranged from approximately $10 \%$ to $35 \%$, suggesting that exploitable differences in cell-wall architecture had occurred as a result of breeding.

A comparison of dry weight loss indicated that treatment with FAE and cellulase usually resulted in improvement over cellulase alone (Fig. 3), suggesting that initial disruption of ester-linked phenolics by FAE makes the cellulose more tractable for cellulase. Of the genotypes within these two populations, 5 and 11 from $\mathrm{C}-1$ population and 2 and 9 from the $\mathrm{C}+3$ population gave the highest dry matter digestibilities (Fig. 1) and the highest dry weight losses with FAE followed by cellulase (Fig. 2). Genotype 5 released higher amounts of $p \mathrm{CA}$ and FA with the two enzyme treatments (about 5\% and 11\%, respectively, of these phenolic acids in starting material). Genotypes 9 and 11 released the highest amounts of Xyl and Glc after the dual enzyme treatment. Genotypes 9 and 11 appear to offer the greatest promise as bioenergy crops for these parameters.

Two phenolic acids, $p \mathrm{CA}$ and FA, constitute the greatest amount of esterified phenolic acids in most grasses. In Bermuda grasses, FA is often higher in amount in the lignocellulose and is released by FAE and cellulase in higher amounts [31]. In napier grass, more $p$ CA than FA is released (Akin, Morrison, and Anderson, unpublished data).

Finally, FA offers promise of a value-added co-product for use in conversion to vanillin, use as ethyl ferulate in cosmetics, and use as an antioxidant. Uses of $p \mathrm{CA}$ as co-products are not as well developed. With the less substitution on the aromatic ring than FA, $p \mathrm{CA}$ may offer advantages as a natural resin for composites. Further, pCA is more toxic than FA, and products with higher levels of $p \mathrm{CA}$ may be developed as antimicrobial agents against difficult-to-control pests [31].

Acknowledgments We thank Nathan Palmer, Ashley Hejny, Ashley Sternhagen, Megan Poppas, and Luanne L. Rigsby for technical assistance. The authors gratefully thank W. Herbert Morrison III, ARSUSDA (retired), for his contributions on chemical analyses. Mention of trade names or commercial products in this publication is solely for the purpose of providing specific information and does not imply recommendation or endorsement by the US Department of Agriculture.

\section{References}

1. Vogel, K. P. (1996). Journal of Soil and Water Conservation, 51, 137-139.

2. Vogel, K. P., Brejda, J. J., Walters, D. T., \& Buxton, D. R. (2002). Agronomy Journal, 94, 413-420.

3. McLaughlin, S. B., \& Kszos, L. A. (2005). Biomass \& Bioenergy, 28, 515-535.

4. Parrish, D. J., \& Fike, F. H. (2005). Critical Reviews in Plant Sciences, 24, 423-459.

5. Sanderson, M. A., Adler, P. A., Boateng, A., Casler, M. D., \& Sarath, G. (2006). Canadian Journal of Plant Science, 86, 1315-1325.

6. Dien, B. S., Jung, H. G., Vogel, K. P., Casler, M. D., Lamb, J. F. S., Weimer, P. J., et al. (2006). Biomass \& Bioenergy, 30, 880-891.

7. Boateng, A. A., Hicks, K. B., \& Vogel, K. P. (2006). Journal of Analytical and Applied Pyrolysis, 75, 55-64.

8. Kaylen, M. S. (2005). Bioresource Technology, 96, 1943-1949.

9. Boylan, D., Bush, V., \& Bransby, D. I. (2000). Biomass and Bioenergy, 19, 411-417.

10. Lau, C. S., Carrier, D. J., Howard, L. R., Lay Jr., J. O., Archambault, J. A., \& Clausen, E. C. (2004). Applied Biochemistry and Biotechnology, 113-116, 569-583.

11. Morrow, W. R., Griffin, W. M., \& Matthews, H. S. (2006). Environmental Science \& Technology, 40, 2877-2886.

12. Hultquist, S. J., Vogel, K. P., Lee, D. J., Arumuganathan, K., \& Kaeppler, S. (1997). Crop Science, 37 , 595-598. 
13. Missaoui, A. M., Paterson, A. H., \& Bouton, J. H. (2005). Theoretical and Applied Genetics, 110, 13721383.

14. Martínez-Reyna, J. M., \& Vogel, K. P. (2002). Crop Science, 42, 1800-1805.

15. Smart, A. J., Vogel, K. P., Moser, L. E., \& Stroup, W. W. (2003). Crop Science, 43, 1427-1433.

16. Smart, A. J., \& Moser, L. E. (1999). Agronomy Journal, 91, 335-338.

17. Boe, A. (2003). Crop Science, 43, 63-67.

18. Das, M. K., Fuentes, R. G., \& Taliaferro, C. M. (2004). Crop Science, 44, 443-448.

19. Casler, M. D., \& Vogel, K. P. (1999). Crop Science, 39, 12-20.

20. Vogel, K. P., \& Jung, H. J. G. (2001). Critical Reviews in Plant Sciences, 20, 15-49.

21. Casler, M. D., \& Vogel, K. P. (2001). Crop Science, 39, 12-20.

22. Mitchell, R. B., Vogel, K. P., Klopfenstein, T., Anderson, B., \& Masters, R. (2005). Crop Science, 45 , 2288-2292.

23. Gabrielsen, B. C., Vogel, K. P., Anderson, B. E., \& Ward, J. K. (1990). Crop Science, 30, 1313-1320.

24. Casler, M. D., Buxton, D. R., \& Vogel, K. P. (2002). Theoretical and Applied Genetics, 104, $127-131$.

25. Pedersen, J. F., Funnell, D. L., \& Vogel, K. P. (2005). Crop Science, 45, 812-819.

26. Hopkins, A. A., Vogel, K. P., \& Moore, K. J. (1993). Crop Science, 33, 253-258.

27. Vogel, K. P. (2004). In L. E. Moser, L. Sollenberger, \& B. Burson (Eds.), Warm-season (C 4 ) grasses ASA-CSSA-SSSA Monograph (pp. 561-588). Madison, WI.

28. Vogel, K. P., \& Burson, B. (2004). In L. E. Moser, L. Sollenberger, \& B. Burson (Eds.), Warm-season $\left(C_{4}\right)$ grasses. ASA-CSSA-SSSA Monograph (pp. 51-96). Madison, WI.

29. Vogel, K. P., Sarath, G., \& Mitchell, R. B. (2005). In F. P. O’Mara et al. (Eds.), XX International Grassland Congress: Wageningen Academic Publ., Wageningen, The Netherlands. p 116.

30. Morrison III, W. H., Akin, D. E., Ramaswamy, G., \& Baldwin, D. (1996). Textile Research Journal, 66, $651-656$

31. Akin, D. E., Morrison III, W. H., Rigsby, L. L., Barton II, F. E., Himmelsbach, D. S., \& Hicks, K. B. (2006). Applied Biochemistry and Biotechnology, 129-132, 104-116.

32. Anderson, W. F., Peterson, J., Akin, D. E., \& Morrison, W. H. (2005). Applied Biochemistry and Biotechnology, 121-124, 303-310.

33. Littell, R. C., Milliken, G. A., Stroup, W. W., \& Wolfinger, R. D. (1996). SAS Institute, Inc. Cary, NC.

34. Ehlting, J., Mattheus, N., Aeschliman, D. S., Li, E., Hamberger, B., Cullis, I. F., et al. (2005). Plant Journal, 42, 618-640.

35. Guillet-Claude, C., Birolleau-Touchard, C., Manicacci, D., Fourmann, M., Barraud, S., Carret, V., et al. (2004). Theoretical and Applied Genetics, 110, 126-135.

36. Boerjan, W., Ralph, J., \& Baucher, M. (2003). Annual Review of Plant Biology, 54, 519-546.

37. Anterola, A. M., \& Lewis, N. G. (2002). Phytochemistry, 61, 221-294.

38. Dixon, R. A., Chen, F., Guo, D., \& Parvathi, K. (2001). Phytochemistry, 57, 1069-1084.

39. Humphreys, J. M., \& Chapple, C. (2002). Current Opinion in Plant Biology, 5, 224-229.

40. Akin, D. E. (1989). Agronomy Journal, 81, 17-25.

41. Casler, M. D., \& Jung, H. J. G. (2006). Animal Feed Science and Technology, 125, 151-161.

42. Casler, M. D. (2001). Advan. Agron., 71, 51-107.

43. Passardi, F., Penel, C., \& Dunand, C. (2004). Trends Plant Science, 9, 534-540.

44. MacAdam, J. W., \& Grabber, J. H. (2002). Planta, 215, 785-793.

45. Jung, H. J., \& Casler, M. D. (2006). Crop Science, 46, 1793-1800.

46. Sarath, G., Vogel, K. V., \& Mitchell, R. B. (2005). In F. P. O’Mara et al. (Eds.), XX International Grassland Congress: Wageningen Academic Publ., Wageningen, The Netherlands. pp 115. 